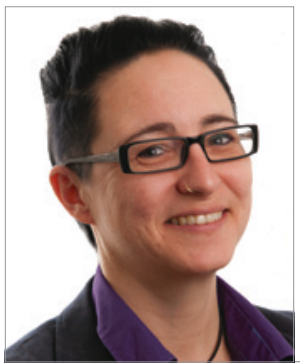

Monica Wegling

Dr.philos.

Foto: Carine Fløystad

\title{
Språket og den trivielle sykdommen
}

Jeg hørte det godt. Svært god faktisk, det var tross alt jeg selv som sa det: «Det er jo helt sykt!»

Det jeg lot diagnostisere, med relativt høy stemme og tydelig diksjon, var at varen med de edleste dråper, dyrket og bearbeidet i det franske Champagne-distriktet ifølge ordboken nå kunne staves med «sj»" - sjampanje. Vel, vi kan alle være enig om at det er uhyrlig. Ja, uhørt. Men sykt? Tja, så lenge sykdom må sies å være et fenomen både uønsket og som regel plagsomt, burde begrepet kanskje kunne overføres til begredelige tilstander generelt også språket.

Problemet er bare at sykdomsbetegnelser og diagnoser fordeles også når tingenes tilstand er over gjennomsnittet gledelig. For kort tid tilbake kom følgende utsagn meg for øret, denne gangen med begeistring og iver: «Du er jo gal!». Nå dreide det seg ikke om en sak, snarere var det en beskrivelse av en person - en relativt sedat kvinne tidlig i de fryktede 40-årene. Det den stakkars kvinnen hadde gjort som avstedkom slike begeistrede hvin, var å melde seg på Birkebeinerrennet. Ja, Birken, og det uten engang å ha sett et skispor de siste par tiår. En panisk øvelse som følge avalder, vil noen si. Andre vil mene det grenset til overmot og at hun var nokså dum. Men psykisk syk? Var hun ikke ved sine fulle fem? Var hun virkelig sinnsforvirret? Hadde hun behov for behandling?

Vi kan følgelig slå fast at diagnostisering skjer både når noe er aldeles galt og når vi skal uttrykke sann fryd. Og - i begge tilfeller - uten at det har noe som helst med helsen vår å gjøre.
Språket er en grunnleggende verdiformidler og en tung kulturbygger. Hvis språket ikke hadde hatt en så sterk betydning, ville begreper som neger, flatbanker, mongo og soper vært flittig benyttet av folk og drott, og verken Språkrådet eller Kringkastingsrådet hadde hatt stort å ta seg til.

Språket kan også sies å være en ledende indikator for endringer i kulturen, og bør derfor kunne fortelle oss noe om sykdommens plass og status. For hva sier vi egentlig når noe er sykt bra (bortsett fra at det er sykt bra selvsagt)? Det er nærliggende å tolke det som en refleksjon av den tendensen som blir sterkere for hvert pulsslag, nemlig at kulturen er fylt til randen av sykdom, lidelser og behandlingsbehov.

Men vi kan også se det fra en annen vinkel. Sykdomsreferanser i språket kan være en refleksjon av sykdommens manglende betydning, på dens ufarlighet. Det kan være et tegn på at sykdom ikke lenger er truende. For når også det fantastiske er helt sykt, er kanskje det å være syk og behandlingstrengende heller ikke så farlig, ja, kanskje til og med helt ok?

Et eksempel er blodtrykket. Høyt blodtrykk er som kjent en sterk risikofaktor for hjerteinfarkt, og det er særlig eldre eller folk med stor stressbelastning i hverdagen som rammes. Men høyt blodtrykk kan reguleres med medikamenter, og dødsfaren dempes. Dermed behøver ikke høyt blodtrykk oppleves som livstruende, og tilstanden kan fylles med ny mening. Høyt blodtrykk blir i stedet en del av overgangsritualet fra voksen til gammel. Høyt blodtrykk som skyldes stress og hektiske dager, blir en symbolsk indikator på å ha hektiske hverdager, som igjen betyr at man er viktig og uunnværlig. Det vi egentlig behandler for, risiko for hjertekomplikasjoner, kommer i annen rekke.

At selve sykdommen kan være udramatisk og triviell, reflekteres også i at nokså naturlige tilstander utstyres med diagnoser og behandlingstilbud. Hårtap kan være alvorlig for den det gjelder, for all del, men om man liker det eller ikke, er det en helt normal del av det å eldes. Når hårtap blir definert som en behandlingsverdig helsetilstand, sågar oppført i ICD-10, bidrar det selvsagt til å skape større behandlingsbehov av ufarlige tilstander. Men ikke minst bidrar det til alminneliggjøring av sykdom og sykdomsbegrepet.

Aksepten for at risikotilstander og naturlige prosesser som medfører ubehag skal behandles, gir oss åpenbart mer sykelighet, mer behandling og flere pasienter. Men det er noe annet som skjer når sykdom og behandlingsbehov blir regelen fremfor unntaket. Vi får en nær og dagligdags knytning til helsetjenesten. Vårt forhold til sykdommer, leger og medisindepotet blir like alminnelig som til tarmgass, postmannen og den lokale puben.

Så når det er helt sykt å endre rettskrivningsregler og galskap å melde seg på birken, får vi et klart og greit signal om sykdommenes status og posisjon i dag. For ofte er helsetilstanden vi diagnostiserer og behandler faktisk like harmløs som å endre skrivemåten til Champagne. Den er bare litt mindre smertefull.

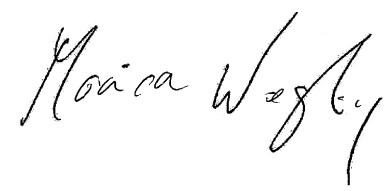

